\title{
\begin{tabular}{l|l} 
Mibraries & DSpace@MIT
\end{tabular}
}

\author{
MIT Open Access Articles
}

\section{Can Electronic Procurement Improve Infrastructure Provision? Evidence from Public Works in India and Indonesia}

The MIT Faculty has made this article openly available. Please share how this access benefits you. Your story matters.

Citation: Lewis-Faupel, Sean, Yusuf Neggers, Benjamin A. Olken, and Rohini Pande. “Can Electronic Procurement Improve Infrastructure Provision? Evidence from Public Works in India and Indonesia." American Economic Journal: Economic Policy 8, no. 3 (August 2016): 258-283. (C) 2017 American Economic Association

As Published: http://dx.doi.org/10.1257/pol.20140258

Publisher: American Economic Association

Persistent URL: http://hdl.handle.net/1721.1/110241

Version: Final published version: final published article, as it appeared in a journal, conference proceedings, or other formally published context

Terms of Use: Article is made available in accordance with the publisher's policy and may be subject to US copyright law. Please refer to the publisher's site for terms of use. 


\title{
Can Electronic Procurement Improve Infrastructure Provision? Evidence from Public Works in India and Indonesia
}

\author{
By Sean Lewis-Faupel, Yusuf Neggers, \\ Benjamin A. Olken, and Rohini Pande*
}

\begin{abstract}
This paper examines whether electronic procurement (e-procurement), which increases access to information and reduces personal interactions with potentially corrupt officials, improves procurement outcomes. We develop unique datasets from India and Indonesia and use variation in adoption of e-procurement within both countries. We find no evidence of reduced prices but do find that e-procurement leads to quality improvements. In India, where we observe quality directly, e-procurement improves road quality, and in Indonesia, e-procurement reduces delays. Regions with e-procurement are more likely to have winners come from outside the region. On net, the results suggest that e-procurement facilitates entry from higher quality contractors. (JEL D72, H54, H57, L12, O17, O22, R42)
\end{abstract}

ontestable government procurement of goods and services has been estimated at over 7 percent of world gross domestic product (GDP) (OECD 2002), with the incidence rising in emerging economies. For instance, in 2007, the Indian government spent over US\$21 billion ( $\$ 18$ per capita) on the procurement of external goods and services, over double what it spent in 2000 (International Monetary Fund (IMF 2008)). Yet, both the quantity and quality of recently constructed public infrastructure often remain low (Briceño-Garmendia, Estache, and Shafik 2004). A limited supply of local qualified contractors, collusion among contractors, and corruption among public officials have each been cited as important reasons (Kenny 2007).

A number of governments have responded by adopting electronic procurement (henceforth, e-procurement) (Leipold and World Bank 2007). Broadly, e-procurement is the implementation of a technological platform as directed by a potential buyer (a government agency or firm) to facilitate transactions between that

\footnotetext{
*Lewis-Faupel: Department of Economics, University of Wisconsin-Madison, 1180 Observatory Drive, Madison, WI 53706 (e-mail: lewisfaupel@wisc.edu); Neggers: Harvard Kennedy School, 79 John F. Kennedy Street, Cambridge, MA 02138 (e-mail: yneggers@g.harvard.edu); Olken: Department of Economics, Massachusetts Institute of Technology, 50 Memorial Drive Building E52, Room 542, Cambridge, MA 02142 and NBER (e-mail: bolken@mit.edu); Pande: Harvard Kennedy School, 79 John F. Kennedy Street, Cambridge, MA 02138 (e-mail: Rohini_Pande@harvard.edu). We thank three anonymous referees and numerous seminar participants for useful comments, Abhijit Banerjee for many thought-provoking conversations, and Maria Acevedo, Leila Agha, Matthew Levinson, Zejd Muhammad, and Amanda Pallais for outstanding research assistance. Financial support was provided by the International Growth Center.

Go to http://dx.doi.org/10.1257/pol.20140258 to visit the article page for additional materials and author disclosure statement $(\mathrm{s})$ or to comment in the online discussion forum.
} 
buyer and potential sellers of goods and services. Commonly, the practice includes electronic postings by the buyer of products and services desired for procurement. There is often an online method for potential suppliers to offer those goods or services requested by the buyer, under a contract and price either preordained by the buyer or offered by the potential seller. As with traditional procurement, there is typically a method for choosing among contracts or prices offered by the potential sellers. In some cases, this selection process is performed automatically by the technology. ${ }^{1}$ In other cases, e-procurement consists of contracted sellers providing a set of goods or services at fixed prices from which the buyer can choose as needed. Additionally, e-procurement may allow for the electronic transfer of funds as agreed upon in the procurement contract. Finally, the technology can facilitate a review by the buyer of the goods or services delivered by the contracted seller, which may be communicated to the seller, considered when enforcing contracts, and used by the buyer in future procurement decisions. We describe the specifics of the e-procurement reforms in the Indian and Indonesian contexts in the next section.

E-procurement can potentially address three common concerns with manual procurement practices: lack of access to bid information, collusion among bidders, and corruption. By lowering the costs of obtaining information about a tender process, e-procurement may increase the number of firms who can bid. Likewise, it can reduce bidder collusion by providing tender information to firms outside a local cartel, allowing non-cartel firms to participate, and breaking up local bidding cartels. E-procurement can also mitigate corruption by reducing government officials' ability to selectively withhold information or refuse electronic bids from non-favored bidders. Moreover, by ensuring public access to all procurement data, e-procurement enhances transparency and the possibility of public oversight.

However, it is plausible that in low income settings, where information technology coverage and other aspects of state capacity remain low, e-procurement can only affect limited change and can potentially make things worse. Potential contractors (who are currently not in the system) may continue never to learn about available tenders, and cartels and corrupt officials may continue to use strong-arm tactics to prevent entry by such contractors. If many small firms have limited access to the Internet, requiring electronic bids could harm competition.

In this paper we examine the impact of electronic procurement on public works projects in two large emerging economies: India and Indonesia. In India, we examine procurement practices between 2000 and 2009 for a federally funded rural road construction program which is implemented by state road departments, the Pradhan Mantri Gram Sarak Yojana (PMGSY) program. Under this program, roughly 145 road packages were tendered per state per year. In Indonesia, we examine contract data from the national Ministry of Public Works for both construction and consulting (e.g., engineering management and design) contracts each year. On average, 32 consultancy and 58 construction packages per province were issued each year.

\footnotetext{
${ }^{1}$ The system may also allow potential sellers to electronically submit other supporting documentation, such as resumes or technical capabilities, or allow the buyer and potential sellers to communicate electronically. Additionally, e-procurement may be used to record and archive any number of other data points of interest to the buyer.
} 
The gradual rollout of e-procurement (at the state level in India and province level in Indonesia) allows for a difference-in-differences strategy: we compare outcomes in states/provinces before and after the adoption of e-procurement, as well as in those continuing under manual procurement practices, allowing us to quantify the benefits or costs of the practice in both countries.

For both countries, we obtained administrative data on the complete universe of contracts from before and after e-procurement by scraping publicly available information from respective government websites. In Indonesia, we have bidding and final contract data for all tenders; in India, the website publishes final contract data but not the details on individual bids. All told, this leaves us with a dataset of over 20,000 contracts in India and over 14,000 tenders in Indonesia. In addition, in India, we hand collected bidding data on tenders for four states which we use to supplement the administrative data.

We first show that, in both India and Indonesia, e-procurement increases the probability that the winning bidder comes from outside the region where the contract takes place. This is consistent with e-procurement decreasing the costs of submitting bids for those not physically present. We next examine the impact on the ultimate outcomes of interest: price, quality of construction, and timeliness. We find no systematic evidence that electronic procurement lowers prices paid by the government. In Indonesia, the point estimates are consistent with small ( $2-5$ percent) reductions in prices, but these are not statistically significant. In India, final prices are unaffected. Overall, we can statistically rule out (at the 5 percent level) declines in contract values of more than 2.7 percent in India, of more than 6.6 percent for Indonesian consulting projects, and of more than 14.1 percent for Indonesian works contracts.

In contrast, e-procurement led to quality improvements, albeit along different dimensions in the two countries. A first measure of quality is time-overrun in project completion. Reports of corruption of procurement in India typically focus on cases where works are abandoned halfway through or completed in a very tardy manner. In our data we see that 77 percent of road projects in India and around 95 percent of public works projects in Indonesia are completed late. In India, we observe no statistically significant changes in late works, while in Indonesia these declines are large and significant - whereas only 5 percent of conventionally procured construction projects in Indonesia are completed on schedule, 20 percent of electronically procured construction projects are on time.

A separate indicator of quality, only available for India, is an independent audit report on construction quality, which was conducted identically in roads completed under both e-procurement and traditional procurement. According to this measure, we find that e-procurement leads to higher quality roads, with the quality grades rising by about 12 percent in e-procurement projects compared to other projects.

We then explore the degree to which the results are driven by improving outcomes among already winning bidders, as opposed to changing who wins. To see whether the observed changes in outcomes reflect changes in selection of who wins, for the key variables of interest-price, delays, and quality-we estimate a fixed effect for each contractor and examine how e-procurement changes the average quality characteristics of winning contractors (i.e., the fixed effects of who wins). 
We find that after e-procurement, winning contractors in India tend to be those who have higher quality on average. In Indonesia, we find evidence that those contractors who win after e-procurement are systematically less likely to be late. This suggests that a key mechanism for e-procurement is allowing higher quality contractors to enter and win projects, rather than simply encouraging better performance from an existing set of contractors. Increased entry of contractors could reflect better information flows and/or reduced ability of local contractors to prevent others from filing tenders.

This paper is related to several economic literatures. While there is a growing body of work which examines procurement (Bandiera, Prat, and Valletti 2009; Krasnokutsaya and Seim 2011), much of the literature has focused on the award procedures (i.e., scoring auctions versus lowest-price auctions, etc.) (Tran 2008) and potential interactions with other procurement regulations (Decarolis 2014). This paper suggests that an important component, at least for ensuring quality, can be in the implementation of the procurement auction, holding these rules fixed. It also contributes to a growing literature using procurement data to examine corruption (Di Tella and Shargrodsky 2003; Ferraz and Finan 2008; Bandeira, Prat, and Villetti 2009; Bobonis, Fuertes, and Schwabe 2010; Cai, Henderson, and Zhang 2013).

Second, past work has highlighted the role of media and technology in shaping the political and policy landscape. Strömberg (2004) suggests that media access among constituents may make politicians more responsive to voters, while Falck, Gold, and Heblich (2014), Jaber (2013), and Campante, Durante, and Sobbrio (2014) measure causal impacts of Internet access on political participation. Our paper complements this previous literature by considering how new technology, in this case implemented by government itself, may improve the outcomes of a government initiative.

Finally, this paper is part of a recent, broader agenda that documents the role of communication technology in development. While there are several studies that document the impact of cell phone technology on market access (Jensen 2007; Aker 2010) and education (Aker, Ksoll, and Lybbert 2012), this paper represents one of the first studies to examine the impact of the Internet on governance issues.

One advantage of our approach is that we use the same methodology to study separate e-procurement programs in two different countries. To the extent that the findings from both countries are similar, the external validity of our results is given credence. To the best of our knowledge, this study represents one of the first microeconomic studies that uses difference-in-differences to simultaneously evaluate a new program in multiple countries, allowing for more careful conclusions with respect to external validity. . $^{2}$

The paper is structured as follows: In Section I, we describe the institutional details relating to procurement practices and road construction in India and Indonesia. In Section II, we describe the data and empirical strategy. In Section III, we report the findings. Section IV concludes.

\footnotetext{
${ }^{2}$ The other study of this nature we are aware of is Gruber and Mullainathan (2005), which evaluates the impact of state and provincial cigarette tax changes in the United States and Canada.
} 


\section{Background}

We start by describing the public works programs in our two study countries, followed by the nature of e-procurement adopted in these two settings. We conclude the section with a brief description of likely channels of influence of e-procurement.

\section{A. India}

Public Works Program and Manual Procurement.-In the year 2000, India launched a large-scale rural road construction scheme called "Pradhan Mantri Gram Sarak Yojana" (PMGSY). The federal government provides funding for this scheme and coordinates program implementation, but full executional responsibility lies with state governments. Each state has a rural roads department which decides the schedule for road construction and manages procurement. PMGSY roads follow uniform criteria for road construction in terms of material usage and quality for all Indian states.

For PMGSY, all states use the same procurement rules and standardized bidding document, provided by the national roads agency. The procurement process follows a cost-based auction procedure. Specifically, conditional on meeting a prespecified set of technical qualifications intended to ensure a contractor is capable of completing the project, the contract is awarded to the lowest bidder. Importantly, these rules are identical for manual and electronic procurement.

Anecdotally, public procurement in India is rife with corruption, and claims of impropriety exist throughout the contracting process. Contractors have reported being physically intimidated or barred from submitting bidding documents. The handling of bidding documents after submission has also been called into question with claims of altered bids, inspection of bids prior to technical reviews, and intentional loss of submissions. There is also concern that technical qualifications are used to unreasonably exclude certain firms from the bidding process. The implication of many of these reports is that government officials collect rents in exchange for some advantage in the bidding process.

As a case study, we examined the tendering process for manual procurement for a random sample of 188 road contracts issued between 2001 and 2005 in the Indian state of Uttar Pradesh. As Figure 1 shows, there is very little competition in PMGSY contracts. In 95 percent of cases, the price bid of only one firm was evaluated; that is, there was only one bid submitted or all other bids were disqualified based on technical requirements. When we observe multiple bids here, over three quarters of the time all but one bid are disqualified. In the case of any technical disqualification, all but one bidder are disqualified 100 percent of the time. Prima facie this pattern of disqualifications is consistent with corrupt officials enforcing a desired winner.

In 2000, when the program began, all Indian states used a manual paper-based procurement system to bid out contracts to private contractors. This process involved obtaining internal approval of the project, publishing a Notice Inviting Tenders (NIT) in several media outlets (typically newspapers), having suppliers obtain detailed bid preparation materials from the government, receiving bid submissions 


\begin{tabular}{lccccr} 
& \multicolumn{5}{c}{ Number of technical disqualifications } \\
\cline { 2 - 6 } Number of bidders & 0 & 1 & 2 & 3 & 4 \\
\hline 1 & 155 & 14 & & & \\
2 & 5 & 1 & 5 & 4 & \\
3 & 3 & & & & 1 \\
4 & & & 5 & 4 & 1 \\
5 & 164 & 14 & 5 &
\end{tabular}

Figure 1. Number of Contracts by Number of Technical Disqualifications AND NUMBER OF BIDDERS

\begin{abstract}
Notes: This figure presents bidding data from a random sample of 188 road contracts issued between 2001 and 2005 in the Indian state of Uttar Pradesh (prior to e-procurement). Each cell is a count of tenders with the respective number of bidders and technical disqualifications. Technical disqualifications are intended to prevent a bidder who lacks the necessary expertise or equipment from competing. Blank cells indicate zeros. Note that the diagonal comprises all cases of all-but-one disqualified.
\end{abstract}

from suppliers, receiving bid evaluations by buyers, and finally, the awarding of the procurement order and signing of agreements. The complete process required a long chain of internal authorizations (at times involving several departments), several visits by suppliers to departments, and the generation of reams of paper-based statements and evaluations.

E-procurement.-The Indian IT Act of 2000 provided legal recognition to electronic transactions. Since then, several Indian states have passed legislation enacting e-procurement, and the rural roads department in several states followed by adopting e-procurement practices for road construction. The implementation of e-procurement for PMGSY typically involves placing all invitations for tender into an online, searchable database. An online portal is also established that allows authorized users (contractors) to upload bidding materials. The Indian e-procurement systems prohibit procurement officials from viewing contractor names and viewing or editing price bids before completing the technical certification process, in theory preventing favoritism in the selection process. Given the above description of how most bidders are disqualified during the technical stage, this is potentially important for preventing corrupt practices. Finally, much of the electronic data is stored after auctions are completed, creating the potential for accountability.

We exploit this variation across time and states for our empirical analysis. Our sample covers 27 Indian states and territories during the period January 2000 through August 2009. During this time frame, nine states adopted a system of electronic procurement. Figure 2, panel A shows the dates when e-procurement rules were adopted in various states through August 2009. The first state to adopt, in 2004, was Andhra Pradesh, which (along with Karnataka) is one of the technological leaders of India. (Note that in some states (Chattisgarh, Gujarat, and Orissa), contracts which are below a state-specified cost threshold do not go through the electronic procurement process and are processed on paper. Since the threshold may respond endogenously to the auction policy (see, e.g., Tran 2008), during the applicable periods, we classify all projects as electronically tendered in these states.) 
Panel A. E-procurement adoption-India

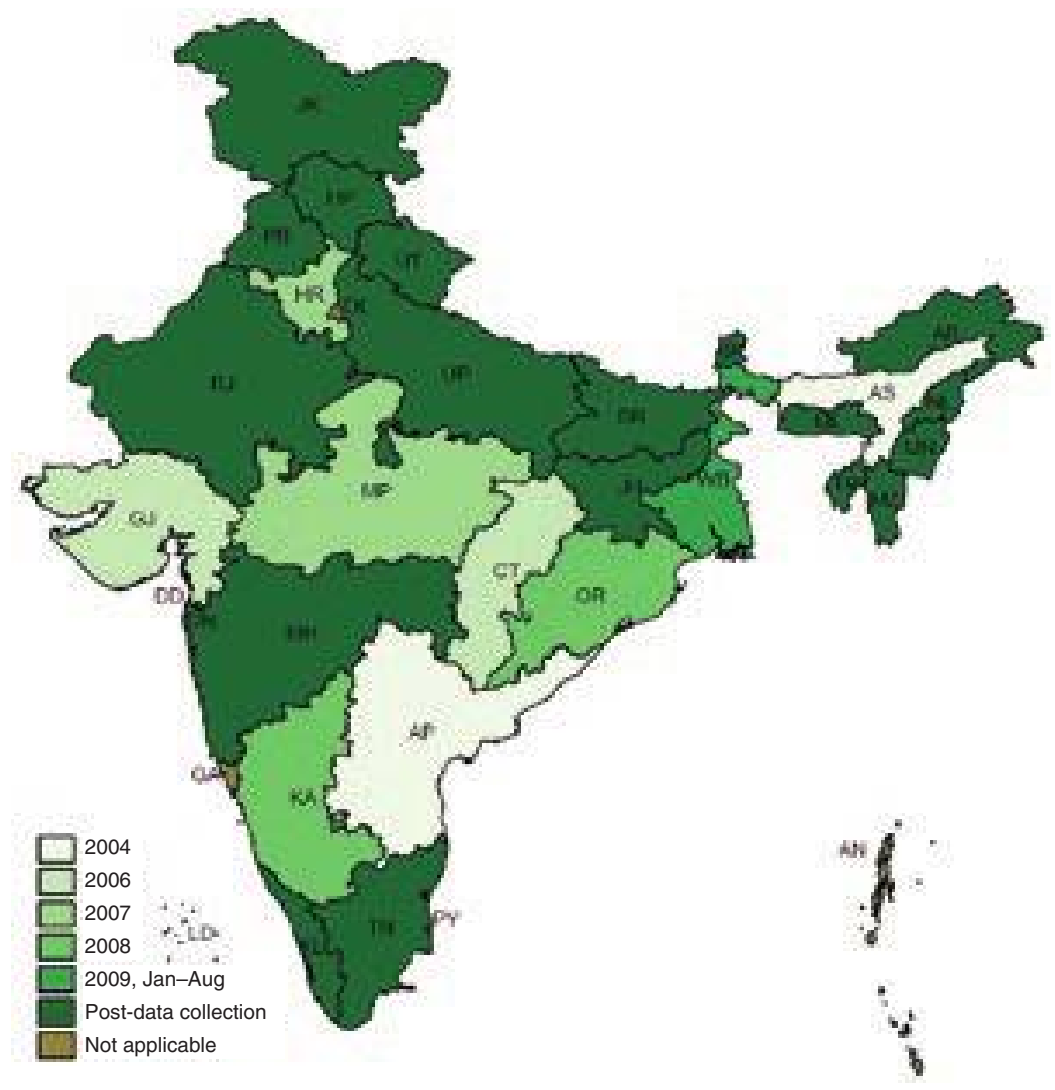

Panel B. E-procurement adoption-Indonesia

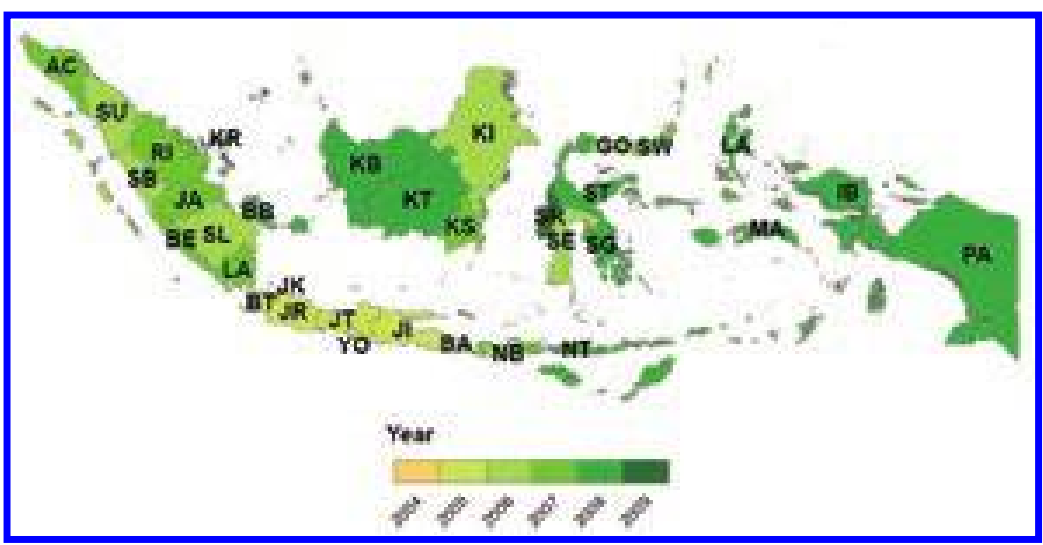

Figure 2. E-PROCUREMENT AdOPTION 


\section{B. Indonesia}

Public Works Program and Manual Procurement.-In Indonesia, we examine the national Ministry of Public Works (MPW). The MPW procurement process covers mainly two types of contracts-works and consulting. Works contracts refer to projects such as the building or repairing of roads and bridges, where physical services or construction work are conducted by the contract winner. Access to heavy equipment and various construction materials is therefore typically a necessary component for these projects. Consulting contracts, in contrast, entail the provision of professional expertise by the winning bidder in planning or supervision services such as design and management. Depending on the project, procurement takes place either at the national headquarters in Jakarta or at the provincial offices of the MPW.

Works and consulting contracts additionally differ in the structure of their bidding processes. Works contracts are generally assigned to the low bidder conditional on meeting minimum administrative and technical qualifications, as in India. Consulting contracts involve a prequalification phase in which potential bidders first submit a document containing administrative, financial, and work experience information. A shortlist of firms meeting minimum qualification requirements are then invited to submit technical and cost bids. The winning bidder is assigned using a formula based on a combination of technical score and price, rather than simply lowest bid conditional on meeting minimum technical requirements as with works projects. For both types of contracts, a minimum of three bid submissions are required; otherwise, the processes are repeated. The overall pool of bidding firms consists of both private firms and state-owned construction firms, with state-owned firms competing against the private sector without any special preferences.

Public procurement is widely considered "one of the most corruption-ridden sectors" (Freedom House 2012) in Indonesia. For example, the 2009 Enterprise Survey of Indonesia (World Bank International Finance Corporation 2009) sampled 1,444 firms comprising a representative sample of the nonagricultural formal private economy in the country. In the survey, 38.1 percent of respondents who had attempted to secure a government contract in the previous year indicated that firms with characteristics similar to theirs make informal payments or give gifts to public officials to secure such contracts, though the average value given for these bribes was only 1.8 percent of the total contract value. A separate survey of 792 randomly sampled construction, consulting, and supplier firms conducted in 2010 by the Indonesia Procurement Watch (Indonesia Procurement Watch 2011) provides further suggestive evidence of corruption in the government procurement process, with 92.7 percent of respondents answering that they thought their firm had ever given bribes to the government officials involved in managing procurement. Additionally, 97.3 percent of respondents believed that it was not possible to win the contract tender without bribery and more than 95 percent indicated that the typical value of a bribe was more than 10 percent of the contract value. Beyond survey results, of the 196 cases considered by the Corruption Eradication Commission (KPK) of the government of Indonesia between 2004 and 2010, 86 dealt with bribery and graft related to the procurement of goods and services, and every such case resulted in a conviction (Onishi 2009, Parlina 2011). 
Anecdotal evidence suggests that the manual procurement process contributes to the corruption problem in much the same ways as discussed in India. For example, government officials may not make the detailed documents required to prepare a bid available to non-favored firms or purposely misinform them about the proper submission process (UNAFEI 2008). Alternatively, there could be physical intimidation of firms that are not part of the cartel from submitting bids.

E-procurement.-Indonesia began rolling out a "semi-electronic procurement" (SEP) system in 2004 in the central ministry in Jakarta and expanded the procedure across the 33 provincial offices in approximately concentric circles from Jakarta over the next 5 years, as shown in Figure 2, panel B. The rollout plan was devised from Jakarta and followed a standard pattern in Indonesia: rollout started in Java, spread to the most developed provinces in Sumatra and Sulawesi next, and then was progressively rolled out throughout the country. Under SEP, firms are able online to register expressions of interest, to download detailed bidding and technical qualification documents, to submit prequalification materials, and to post questions and complaints. However, due to a regulatory constraint, the final submission of bids was still required to be conducted manually (hence the term "semi") throughout the period we study. The SEP process thus covers the entire procurement process except the final submission of bids. There was no change in procurement rules associated with the switch to SEP; procurement still followed the presidential guidelines for the procurement of government goods and services issued in 2003 (Government of Indonesia 2003). ${ }^{3}$

Prior to the adoption of SEP in a province, procurement was in a "copy-to-Internet" (CTI) phase where the acquisition of bidding and technical qualification documents and the submission of bids were carried out manually, but the contract details (bids of each firm and the winner) were posted to the Internet ex post to be publicly available. Crucially for our analysis, the data made public during the copy-to-Internet and semi-e-procurement systems are identical and in fact use the same electronic platform; the only difference is that procurement actually takes place electronically on the SEP system, whereas in copy-to-Internet, information is just released publicly ex post. We discuss the data in more detail below.

\section{E-procurement: Channels of Influence}

There are several mechanisms through which e-procurement could affect outcomes. First, e-procurement could change the composition of bidders. By placing bidding documents online and allowing interactions online rather than in person, e-procurement facilitates bidding at a distance; on the other hand, since it requires Internet access, it may be more difficult for unsophisticated bidders. Second, e-procurement may increase the enforcement of government rules and regulations. In the manual procurement system, the paper trail and threat of audit ensure that rules are complied with, but this is imperfect; e-procurement adds an additional layer of

\footnotetext{
${ }^{3}$ Full e-procurement was not introduced until after the period under study.
} 
intermediation, where the computer system itself enforces certain procedures. Third, e-procurement may prevent denial of access to non-favored suppliers. For example, in a manual procurement system, a procurement official could, for a supplier outside of a prespecified cartel, claim that there were no copies available of bidding documents or refuse to accept a bid. The e-procurement system cannot be manipulated in this way and provides access to all equally. Finally, even if outcomes are not changed, if e-procurement costs less for the government to administer than a manual procurement process, it could still be beneficial to the government (Singer et al. 2009).

The impact of these changes on prices and quantities is ambiguous for several reasons. First, while most of these effects of e-procurement are "positive" (in the sense of increasing competition and/or reducing the possibility of corruption or collusion), there is one potential downside, namely that it may make access more difficult for bidders with low Internet availability or low levels of computer skills.

Second, even conditional on "improving" outcomes for the government, it is not ex ante obvious whether this improvement will come in the form of lower prices, improved quality, or both (Asker and Cantillon 2010). If e-procurement facilitates the entry of high quality firms from farther away (say, high quality firms located in the capital city), one might expect quality to rise; prices might even rise as well. On the other hand, if e-procurement facilitates the entry of more firms of similar quality, the impact could either be a fall in prices (if existing firms bid the same quality as before but reduce prices in light of more competition) or an increase in quality (if existing firms increase quality of their proposals for the same price). Either way, these ambiguities suggest that it is important to measure the impacts on both prices and quality when considering the net impact for the government.

These arguments hold true under a competitive model with no collusion or corruption, but similar arguments can be made in cases of corruption, as well. For example, in a corrupt world where the most efficient contractor can pay the highest bribe (as in Tran 2008 and Asker 2010), e-procurement, even if it eliminated the bribes, would not necessarily change the identity of the firm winning the contract (Burguet and Che 2004). It would, however, potentially reduce the price. On the other hand, if there was heterogeneity in firms' willingness to pay bribes, so the most efficient firm was not necessarily the one with the highest willingness to pay, eliminating corruption might also result in a different firm winning the contract and potentially higher quality (Celentani and Ganuza 2002).

Of course, all of these effects could potentially be muted if the requests for proposal changed in response to e-procurement. For example, one might imagine that in response to an intervention that made it more difficult for a procurement officer to direct a contract to a particular bidder, the officer might change the contract requirements such that only the desired firm could satisfy them. While this issue could arise, at least in India this is unlikely to be a major force since the Indian road specifications are largely fixed by PMGSY program guidelines.

\section{Data and Empirical Strategy}

In this section we describe the Indian and Indonesian datasets, followed by our empirical strategy. 


\section{A. Data}

India.-We obtain administrative data on costs, quality, and delays associated with each PMGSY contract issued between January 2000 and August 2009 from multiple PMGSY websites. The dataset covers 27 Indian states. For PMGSY, some road packages (sets of construction projects and funding allocated by the federal government) are split into multiple tenders, each with its own contract covering a subset of roads in the package. As a result, our final dataset covers (at least partial information for) 30,578 packages and 35,610 associated contracts.

A first set of outcomes are the cost outcomes associated with each contract. The estimated cost is the amount budgeted (or "sanctioned" in the terminology of PMGSY) by the national authority for construction of a specific road or set of roads in a package. A contract or payment above this amount can only occur with permission from the national offices. The contract value is the amount the government agrees to pay the winning firm for the relevant work. The final payment records the total amount paid out for each package, which as discussed above, may be distributed among multiple contracts and includes any amendments to the contract that occur during construction.

We have measures of two key aspects of project quality: timeliness and physical project quality. For timeliness, we track the time to execution. We use "late completion," which is an indicator variable taking value one if road construction work is not completed by the date agreed to in the initial contract. We also construct a continuous "time overrun ratio" variable, which is the ratio of actual to agreed upon time to completion.

To measure the quality of project implementation, we use quality reports submitted by the National Quality Monitors (NQMs). During construction, PMGSY has a multitier quality monitoring system, with local, state, and national monitoring. National monitoring is conducted by NQMs, who are retired engineers from other states. The assignment of packages to NQMs is randomized and is therefore conducted similarly in places with and without electronic procurement. ${ }^{4}$ We focus on the outcomes of this national monitoring as our quality outcome. NQMs evaluate each part of the work for material and workmanship as per the format of the standardized "NQM Inspection Report," indicating the tests carried out and the test results obtained. Overall grading includes management issues, contract management, and quality of work. We use a binary assessment (satisfactory/unsatisfactory) of the technical fitness of the road at the time of inspection.

For a subset of packages in the states of Andhra Pradesh, Chhattisgarh, Karnataka, and Uttar Pradesh, we have bidding data. This includes the total number of bids submitted in each auction. Before submitted bids are unsealed, engineers in each state decide which firms have the technical ability (in training, equipment, and experience) to complete the project based on materials firms submit with their bid. We

\footnotetext{
${ }^{4}$ The NQMs are given the letter of request once every two months for carrying out inspection for the forthcoming two months. The NQMs are required to inspect three districts in a single visit in one state in each of the two months. The letter of request allocates a mix of works in progress and completed works. The letter indicates the specific location of works to be inspected and which are in-progress or completed works. Within a block (the administrative unit below district), projects to be inspected are chosen on a random basis.
} 
also observe how many of the submitted bids in each auction are judged to be from technically qualified firms.

Indonesia.-We scraped data from the CTI and SEP websites of the Indonesian Ministry of Public Works, capturing the complete universe of procurement from 2004 through 2008. Over 14,000 contracts from the MPW national headquarters and the 33 provincial offices are covered. Each entry in the data is at the contract level and specifies the estimated cost, which is, as in India, the maximum amount allowed by the MPW to be paid for a given contract. Information on the type of project is available, as are all bidder names, bid amounts, disqualifications, and final contract values.

We also have the dates on which the notice and details for each contract were first posted online (and concurrently in traditional media), as well as the dates of bid opening and contract award. For road projects (which represent a subset of all projects covered by the Ministry of Public Works), we have a separate database from the road division that tracks the start dates and expected and actual completion dates for the services associated with each contract. As with India, we construct "late completion" and "time overrun" variables. No direct quality measure is available for Indonesia. For regressions which consider as an outcome variable the above measures of the timeliness of completion, the number of firms expressing interest (i.e., registering to access bidding documents), or the number of firms bidding, we trim the top and bottom 1 percent of sample observations.

\section{B. Descriptive Statistics}

In the first column of Table 1, we present a set of basic descriptive statistics for the Indian data, and in the remaining columns we present statistics from Indonesia. All monetary variables are in logs, which is the form in which they will be used in the regressions below.

Examining the Indian data, in an average year for the typical state, the government sanctioned almost 145 packages worth 9.61 log lakh rupees (approximately US\$33 million at exchange rates for 2005, the midpoint of our dataset; 1 lakh is 100,000 rupees) covering over $6.74 \log$ kilometers (525 miles) of road. At the package level, the average log estimated cost of completion over the period observed is $5.21 \mathrm{log}$ lakh rupees (about US\$416,000). In the subset of auctions for which we have bidding data (as discussed above, these are from 4 states), there are an average of 2.7 total bids and 1.7 qualified bids.

One contract per package is the mode, but a long right tail is observed. On average, a package is associated with 1.25 contracts for which we have data. Roads contracts generally come in below estimated cost (most likely because exceeding estimated cost requires an additional bureaucratic process). However, cost overruns with respect to the contracted price are relatively common post-contracting. The average payment on completed projects exceeds the average contract value by about 46 percent.

Turning to delays and quality, completion before the contracted due date was rare, with more than three-quarters of contracts finished after the assigned deadline and an average delay of 244 days. There was heterogeneity in quality, with 72 percent of projects receiving a satisfactory quality rating on first inspection. 
Table 1 -Summary Statistics

\begin{tabular}{|c|c|c|c|c|c|c|c|c|}
\hline & \multicolumn{4}{|c|}{ India } & \multicolumn{4}{|c|}{ Indonesia } \\
\hline & \multicolumn{2}{|c|}{ All } & \multicolumn{2}{|r|}{ All } & \multicolumn{2}{|c|}{ Works } & \multicolumn{2}{|c|}{ Consulting } \\
\hline & $\begin{array}{l}\text { Mean } \\
\text { (SD) }\end{array}$ & Observations & $\begin{array}{l}\text { Mean } \\
(\mathrm{SD})\end{array}$ & Observations & $\begin{array}{l}\text { Mean } \\
(\mathrm{SD})\end{array}$ & Observations & $\begin{array}{l}\text { Mean } \\
(\mathrm{SD})\end{array}$ & Observations \\
\hline \multicolumn{9}{|c|}{ Panel A. State/province year level } \\
\hline Total projects & $\begin{array}{c}144.8 \\
(184.9)\end{array}$ & 158 & $\begin{array}{c}88.3 \\
(89.1)\end{array}$ & 166 & $\begin{array}{c}57.9 \\
(40.3)\end{array}$ & 164 & $\begin{array}{c}32.2 \\
(61.2)\end{array}$ & 160 \\
\hline log total budget & $\begin{array}{c}9.610 \\
(1.469)\end{array}$ & 158 & $\begin{array}{l}25.674 \\
(0.944)\end{array}$ & 166 & $\begin{array}{l}25.610 \\
(0.918)\end{array}$ & 164 & $\begin{array}{l}22.886 \\
(1.156)\end{array}$ & 160 \\
\hline $\begin{array}{l}\text { Panel B. Package level } \\
\text { log estimated cost }\end{array}$ & $\begin{array}{c}5.211 \\
(0.846)\end{array}$ & 22,378 & $\begin{array}{l}20.540 \\
(1.311)\end{array}$ & 14,657 & $\begin{array}{l}20.952 \\
(1.350)\end{array}$ & 9,502 & $\begin{array}{l}19.780 \\
(0.799)\end{array}$ & 5,155 \\
\hline Contracts in package & $\begin{array}{c}1.251 \\
(1.088)\end{array}$ & 22,378 & & & & & & \\
\hline $\begin{array}{l}\log \text { total value of } \\
\text { contracts in package }\end{array}$ & $\begin{array}{l}5.217 \\
(0.908)\end{array}$ & 22,378 & & & & & & \\
\hline $\begin{array}{l}\text { Satisfactory quality } \\
\text { at first inspection }\end{array}$ & $\begin{array}{c}0.715 \\
(0.451)\end{array}$ & 11,200 & & & & & & \\
\hline $\begin{array}{l}\text { Panel C. Contract level } \\
\log \text { contract value }\end{array}$ & $\begin{array}{c}4.529 \\
(2.044)\end{array}$ & 26,659 & $\begin{array}{l}20.433 \\
(1.322)\end{array}$ & 14,623 & $\begin{array}{l}20.826 \\
(1.381)\end{array}$ & 9,491 & $\begin{array}{l}19.706 \\
(0.799)\end{array}$ & 5,132 \\
\hline log final payment & $\begin{array}{c}4.914 \\
(0.903)\end{array}$ & 14,813 & & & & & & \\
\hline $\begin{array}{l}\text { Completion delay } \\
\text { (days) }\end{array}$ & $\begin{array}{c}244.3 \\
(345.4)\end{array}$ & 13,781 & & & & & & \\
\hline $\begin{array}{l}\text { Number of firms } \\
\text { expressing interest }\end{array}$ & & & $\begin{array}{c}28.837 \\
(32.902)\end{array}$ & 14,409 & $\begin{array}{c}33.468 \\
(38.967)\end{array}$ & 9,329 & $\begin{array}{c}20.333 \\
(13.058)\end{array}$ & 5,080 \\
\hline $\begin{array}{l}\text { Number of firms } \\
\text { bidding }\end{array}$ & $\begin{array}{c}2.756 \\
(3.075)\end{array}$ & 1,628 & $\begin{array}{c}5.842 \\
(4.617)\end{array}$ & 14,521 & $\begin{array}{c}7.298 \\
(5.083)\end{array}$ & 9,414 & $\begin{array}{c}3.158 \\
(1.364)\end{array}$ & 5,107 \\
\hline Time notice to award & & & $\begin{array}{c}99.544 \\
(110.258)\end{array}$ & 10,423 & $\begin{array}{c}84.393 \\
(100.478)\end{array}$ & 6,810 & $\begin{array}{c}128.102 \\
(121.642)\end{array}$ & 3,613 \\
\hline $\begin{array}{l}\text { Time bid open } \\
\text { to award }\end{array}$ & & & $\begin{array}{l}29.616 \\
(29.672)\end{array}$ & 9,199 & $\begin{array}{l}27.476 \\
(24.182)\end{array}$ & 5,975 & $\begin{array}{c}33.583 \\
(37.477)\end{array}$ & 3,224 \\
\hline $\begin{array}{l}\text { Winner won in } \\
\text { first year }\end{array}$ & $\begin{array}{c}0.109 \\
(0.312)\end{array}$ & 34,126 & $\begin{array}{c}0.282 \\
(0.450)\end{array}$ & 9,575 & $\begin{array}{c}0.212 \\
(0.408)\end{array}$ & 6,893 & $\begin{array}{c}0.463 \\
(0.499)\end{array}$ & 2,682 \\
\hline $\begin{array}{l}\text { Winner from same } \\
\text { district/prov. }\end{array}$ & $\begin{array}{c}0.302 \\
(0.459)\end{array}$ & 12,913 & $\begin{array}{c}0.734 \\
(0.442)\end{array}$ & 6,096 & $\begin{array}{c}0.817 \\
(0.387)\end{array}$ & 4,152 & $\begin{array}{c}0.556 \\
(0.497)\end{array}$ & 1,944 \\
\hline Time overrun ratio & $\begin{array}{c}2.262 \\
(3.018)\end{array}$ & 13,628 & $\begin{array}{c}1.876 \\
(0.992)\end{array}$ & 4,161 & $\begin{array}{c}2.179 \\
(0.991)\end{array}$ & 2,986 & $\begin{array}{c}1.083 \\
(0.330)\end{array}$ & 1,175 \\
\hline Late & $\begin{array}{c}0.766 \\
(0.423)\end{array}$ & 13,628 & $\begin{array}{c}0.832 \\
(0.374)\end{array}$ & 4,161 & $\begin{array}{l}0.948 \\
(0.223)\end{array}$ & 2,986 & $\begin{array}{c}0.537 \\
(0.499)\end{array}$ & 1,175 \\
\hline
\end{tabular}

Examining the Indonesian data in Table 1, between 2004 and 2008 the average Indonesian province auctioned about 88 contracts per year, with nearly twice as many works as consulting projects, for a province-level average log total budget of $25.67 \mathrm{log}$ rupiah (approximately US $\$ 15$ million at 2006 exchange rates). At the project level, the average log estimated cost for works projects is $20.95 \log$ rupiah (about US $\$ 140,000$ ) and for consulting projects is $19.78 \mathrm{log}$ rupiah (approximately US $\$ 43,000)$. The final contract value for a given project is on average 10 percent lower than the official estimated cost provided by the government prior to bidding. Firms winning contracts are typically based in the same province as the contract, more than 80 percent so for works projects. As with the data from India, delays are common; nearly all works projects ( 95 percent) and more than half of consulting projects (54 percent) are completed later than the initially agreed upon date. 


\section{Empirical Strategy}

We estimate impacts separately for India and Indonesia. In both cases, we make use of a difference-in-differences strategy, but our implementation differs slightly across countries, as described below.

In India, for road package or contract $i$ in state $s$ which began in year $t$, we estimate the following OLS specification:

$$
y_{i s t}=\alpha_{s}+\beta_{t}+\mu \operatorname{EPROC}_{s t}+\mathbf{X}_{i s t}^{\prime} \gamma+\epsilon_{i s t},
$$

where $i$ is a package or contract, $s$ is a state, and $t$ is a year, and $E P R O C_{s t}$ is a dummy for e-procurement adoption by state $s$ as of year $t$. Controls $X_{i s t}$ are log estimated cost and $\log$ road length. ${ }^{5}$ All regressions include state $\left(\alpha_{s}\right)$ and year $\left(\beta_{t}\right)$ fixed effects. In some cases, we collapse the package-level data to the state level and estimate regressions using annual state-level data. In all cases, we cluster standard errors by state.

In Indonesia, the availability of e-procurement at the province level does not necessarily imply that all projects within a province will be contracted using the system. ${ }^{6}$ To obtain the average impacts of the use of e-procurement, we instrument for actual e-procurement use with the adoption of e-procurement in the province, as follows. The regression of interest (i.e., the second stage) is:

$$
y_{i s t}=\alpha_{s}+\beta_{t}+\text { OEPROCPACKAGE } E_{i s t}+\delta X_{i s t}+\epsilon_{i s t},
$$

where EPROCPACKAGE $E_{i s t}$ is a dummy for e-procurement use in project $i$ in province $s$ as of year $t$. The project level e-procurement variable EPROCPACKAGE $E_{i s t}$ is instrumented with $E P R O C_{s t}$, which is a dummy for whether e-procurement has been adopted by province $s$ as of time $t . .^{7}$ The control variable $X_{i s t}$ is the log estimated cost (since we have many different types of projects and there is no metric available in the data other than estimated cost, we cannot control for road length as for India). Standard errors are clustered by province.

In our regression tables we typically report results for the India sample as panel A, Indonesia works projects as panel B, and Indonesia consulting projects as panel C.

\section{Identification Check}

Since the adoption of e-procurement is not randomly assigned, we need to ensure that the timing of e-procurement adoption is not correlated with differential trends in procurement that would have occurred in the absence of e-procurement.

\footnotetext{
${ }^{5}$ For India, the $R^{2}$ values from regressions of e-procurement on log road length and log estimated cost range from 0.0004 to 0.081 , depending on the year. For Indonesia, the $R^{2}$ values from regressions of project-level e-procurement on log estimated cost range between 0.001 to 0.022 for works projects and between 0.000 to 0.125 for consulting projects, depending on the year.

${ }^{6}$ It is possible that this is true for India as well, but for India we do not observe what fraction of packages actually used e-procurement in a given year.

${ }^{7}$ The first-stage coefficient and $F$-statistic for works projects are, respectively, 0.359 and 40.79 , and for consultancy projects they are 0.491 and 78.11 .
} 
TABLE 2-Budget IMPACT

\begin{tabular}{lcc}
\hline \hline & \multicolumn{2}{c}{ State-year level } \\
\cline { 2 - 3 } & $\begin{array}{c}\text { log (total estimated cost } \\
\text { at state-year) } \\
(1)\end{array}$ & $\begin{array}{c}\text { Number of projects } \\
\text { in state-year } \\
(2)\end{array}$ \\
\hline Panel A. India & -0.041 & -54.391 \\
E-procurement & $(0.089)$ & $(60.717)$ \\
Mean dep. var. (non-eproc) & 9.548 & 139.203 \\
& $(1.413)$ & $(184.074)$ \\
Observations & 157 & 157 \\
Panel B. Indonesia-works projects & & -3.559 \\
E-procurement (IV) & 0.187 & $(7.069)$ \\
& $(0.151)$ & 45.102 \\
Mean dep. var. (non-eproc) & 25.211 & $(28.803)$ \\
& $(0.774)$ & 164 \\
Observations & 164 & \\
Panel C. Indonesia-consultancy projects & & 7.641 \\
E-procurement (IV) & & $(8.486)$ \\
Mean dep. var. (non-eproc) & 0.374 & 15.831 \\
& $(0.226)$ & $(10.009)$ \\
Observations & 22.306 & 160 \\
\hline
\end{tabular}

Notes: India: Column 1 reports estimates from an OLS regression of log total estimated cost at the state-year level on an indicator for any contract being awarded under e-procurement in the respective state and year. Column 2 does the same using number of packages as the dependent variable. Log of road length and log of estimated cost are included as controls when not on the LHS. Indonesia: Columns 1 and 2 give results from OLS regressions at the state-year level, where the dependent variable is given in the table and the independent variable is the official adoption of electronic procurement at the state level. Column 2 includes a control for $\log$ total state-year estimated project cost. Both regressions include state and year fixed effects. Standard errors clustered at the state level are in parentheses below estimates. Means for each dependent variable are also reported, with standard deviations in parentheses.

To examine this, we begin by checking whether, overall, the adoption of e-procurement is associated with a change in the volume (total budget for procurement) or structure (i.e., across how many contracts procurement is distributed) in a given state or province. Column 1 of Table 2 reports regressions where the dependent variable is log total estimated cost at the state-year level and the explanatory variable of interest is an indicator for any contract being awarded under e-procurement, with $\log$ of road length included as a control for India. Column 2 repeats the exercise using number of projects as the dependent variable, controlling for log total state-year estimated project cost. In neither country do we see a significant impact of e-procurement adoption on the total budget allocations (column 1) or the number of projects they are broken into (column 2) at the state/province level, suggesting that e-procurement was not coincident with major changes in the amount or structure of contracts being procured..$^{8}$

\footnotetext{
${ }^{8}$ We find a similar null result for e-procurement's effect on log road length. See online Appendix Table 2 for these estimates.
} 
Second, we examine whether the year of official adoption of e-procurement at the state level (conditional on e-procurement occurring after the first two years in our data - that is, after 2005 in Indonesia or after 2001 in India), is significantly related to the difference in log average contract value between the first two years of the data (i.e., between 2001 and 2000 for India (Appendix Table A1, panel A) and between 2005 and 2004 for Indonesia (Appendix Table A1, panels B and C)). Regressing these early contract value differences on e-procurement can suggest whether differential initial trends predict the year of subsequent e-procurement adoption. We see no correlation between change in state-level contract value and the timing of e-procurement for either India or Indonesia.

\section{Results}

\section{A. Did E-procurement Change the Contracting Process?}

Contracting Execution.-In Table 3 we first examine whether the introduction of e-procurement has an impact on the duration of the project contracting phase. In columns 1 and 2, we consider the time elapsed between tender notice and contract award and between bid opening and contract award. Both variables are available only for the Indonesia sample. While neither variable is significantly impacted for works projects, we find an increase of 54.15 days (statistically significant at the 1 percent level), a more than 50 percent increase, in the time elapsed between the tender notice and awarding of contract for consulting projects. In conjunction with the absence of an effect in column 2 on the amount of time between bid opening and award, this implies that for consulting projects e-procurement increased the period of time between the tender notice and the opening of bidding, in which firms can learn about potential contracts and prepare their bid documents.

Who Bids and Who Wins?-We next consider indicators of changing contractor identity. In column 3 of Table 3, we investigate the impact of e-procurement on the number of firms who express an interest in bidding. These data are only available for Indonesia. For nearly every works project, this process entails registering to be allowed to download the detailed bid documents and participate in bid submission. For all consulting projects and a small subset of works projects, expression of interest involves the submission of a prequalification document on which firms are scored and a subset of those passing are chosen to submit bids. The number of firms expressing interest in the case of works projects more than doubles.

In column 4 we examine the number of firms submitting a complete bid. This number is relatively low in India with the average manual procurement contract receiving roughly 2.9 bids. This number is higher for Indonesia at over 7 bids per works project and 3.2 per consulting project. However, in no instance does the average number of bids increase due to e-procurement.

Column 5 examines whether e-procurement changes the likelihood that the winning firm is based in the same area in which a project is tendered. While a variable for contractor home province was available directly in the Indonesian data, we proxy for firm default location in India with the modal district among those in which the 
Table 3-Contract Process

\begin{tabular}{|c|c|c|c|c|c|c|}
\hline & $\begin{array}{c}\text { Time } \\
\text { elapsed } \\
\text { notice to } \\
\text { award } \\
(1)\end{array}$ & $\begin{array}{c}\text { Time } \\
\text { elapsed } \\
\text { bid open } \\
\text { to award } \\
(2)\end{array}$ & $\begin{array}{l}\text { Number of } \\
\text { firms } \\
\text { expressing } \\
\text { interest } \\
\text { (3) }\end{array}$ & $\begin{array}{l}\text { Number } \\
\text { of } \\
\text { firms } \\
\text { bidding } \\
\text { (4) }\end{array}$ & $\begin{array}{l}\text { Winner } \\
\text { from same } \\
\text { province/ } \\
\text { district } \\
(5)\end{array}$ & $\begin{array}{l}\text { Winner } \\
\text { in } \\
\text { first } \\
\text { year } \\
(6)\end{array}$ \\
\hline \multicolumn{7}{|l|}{ Panel A. India } \\
\hline E-procurement & & & & $\begin{array}{c}0.364 \\
{[0.733]}\end{array}$ & $\begin{array}{r}-0.108 \\
(0.029)\end{array}$ & $\begin{array}{c}0.0222 \\
(0.0218)\end{array}$ \\
\hline Mean dep. var. (non-eproc) & & & & $\begin{array}{c}2.86 \\
(3.52)\end{array}$ & $\begin{array}{c}0.581 \\
(0.493)\end{array}$ & $\begin{array}{c}0.141 \\
(0.348)\end{array}$ \\
\hline Observations & & & & 1,406 & 6,545 & 26,246 \\
\hline \multicolumn{7}{|c|}{ Panel B. Indonesia—works projects } \\
\hline E-procurement (IV) & $\begin{array}{c}48.75 \\
(38.24)\end{array}$ & $\begin{array}{c}-2.54 \\
(6.93)\end{array}$ & $\begin{array}{c}24.735 \\
(13.657)\end{array}$ & $\begin{array}{c}0.420 \\
(1.520)\end{array}$ & $\begin{array}{r}-0.036 \\
(0.057)\end{array}$ & $\begin{array}{c}0.069 \\
(0.060)\end{array}$ \\
\hline Mean dep. var. (non-eproc) & $\begin{array}{c}64.90 \\
(71.20)\end{array}$ & $\begin{array}{c}25.33 \\
(29.43)\end{array}$ & $\begin{array}{c}17.456 \\
(21.460)\end{array}$ & $\begin{array}{c}7.005 \\
(5.057)\end{array}$ & $\begin{array}{c}0.816 \\
(0.387)\end{array}$ & $\begin{array}{c}0.245 \\
(0.430)\end{array}$ \\
\hline Observations & 6,804 & 5,974 & 9,323 & 9,408 & 4,151 & 6,892 \\
\hline \multicolumn{7}{|c|}{ Panel C. Indonesia-consultancy projects } \\
\hline E-procurement (IV) & $\begin{array}{c}54.15 \\
(19.10)\end{array}$ & $\begin{array}{c}9.88 \\
(6.19)\end{array}$ & $\begin{array}{r}-3.489 \\
(2.561)\end{array}$ & $\begin{array}{r}-0.242 \\
(0.281)\end{array}$ & $\begin{array}{r}-0.233 \\
(0.133)\end{array}$ & $\begin{array}{c}0.414 \\
(0.183)\end{array}$ \\
\hline Mean dep. var. (non-eproc) & $\begin{array}{c}98.01 \\
(101.20)\end{array}$ & $\begin{array}{c}26.13 \\
(48.53)\end{array}$ & $\begin{array}{l}11.069 \\
(6.174)\end{array}$ & $\begin{array}{c}3.178 \\
(1.468)\end{array}$ & $\begin{array}{c}0.650 \\
(0.477)\end{array}$ & $\begin{array}{c}0.446 \\
(0.497)\end{array}$ \\
\hline Observations & 3,611 & 3,223 & 5,078 & 5,107 & 1,944 & 2,682 \\
\hline
\end{tabular}

Notes: India: All columns report OLS estimates from a regression at the contract level of the listed variable on an indicator for the contract being awarded using e-procurement. Column 4 is estimated on a subset of contracts for which we have bidding data in the states of Andhra Pradesh, Chhattisgarh, Karnataka, and Uttar Pradesh. Column 5 defines the district that a contractor is from as the modal district of the contractor's observed contracts prior to e-procurement starting anywhere in the country. This regression is therefore restricted to contracts won by the cohort of contractors who were awarded contracts prior to e-procurement. Winner in first year (column 6) is an indicator for the winner having been awarded a contract in 2000 or 2001. This regression is restricted to observations after the first year. State and year fixed effects as well as controls for log of road length and log of estimated cost are included. Indonesia: All columns report IV estimates at the project level, where the dependent variable is given in the table and the independent variable is the contract-level use of electronic procurement, instrumented by the official adoption of electronic procurement at the state level. Values of time elapsed in columns 1 and 2 were available for a subset of provinces in 2004 and all provinces in subsequent years. Column 5 defines the province where the contractor is from as the province directly indicated in the data. This regression therefore excludes contracts based out of the national headquarters. Column 6 defines winner in first year as an indicator for the winner having been awarded a contract in 2004. This regression is restricted to observations after the first year in the data. State and year fixed effects as well as a control for log of estimated cost are included. Standard errors are clustered at the state level. Where brackets are used, $p$-values are given using the wild bootstrap method. Non-e-procurement project means for each dependent variable are also reported, with standard deviations in parentheses.

contractor was observed with contracts prior to e-procurement starting anywhere in the country. $9^{9}$ In general, as with most construction projects, where moving equipment is quite costly and where there is often a need for local sources of materials (e.g., hot asphalt), there is a strong tendency to be local: in India nearly 60 percent of winning bids come from firms located in the same district and in Indonesia over 80 percent of works contracts are won by firms from the same province.

\footnotetext{
${ }^{9}$ In India, the only consistent firm identification data we observe is a unique ID within states, which does not link across states. Since some firms are not observed prior to the start of e-procurement, the location variable is undefined for these firms and the associated observations are excluded from this regression.
} 
We observe a significant 11 percentage point decline in this variable in India and a 23 percentage point decline for consultancy projects in Indonesia. Given that it is much easier to move engineers geographically than to move heavy equipment and asphalt plants, it is not surprising that the impacts for Indonesia-where cross-provincial distances are much greater than the cross-district distances we observe in India - are concentrated among consulting projects.

Finally, we examine in column 6 whether e-procurement changed entry of new firms. Specifically, we examine whether the winning bidder was present and won a contract bid in the first year of our data (2000 or 2001 for districts in India or 2004 for provinces in Indonesia). This regression is restricted to observations that fall in years subsequent to these initial years. We observe a highly significant increase of 41 percentage points for consultancy projects in Indonesia, showing that e-procurement leads to more contracts being won by preexisting winning firms. Combined with column 5, this suggests that e-procurement leads to projects being won by preexisting firms from other provinces.

One consistent explanation for these findings is that e-procurement improves access to information for firms outside the area where procurement is taking place. This is a relatively larger benefit for firms that are farther away and may also favor preexisting firms with a documented record of success.

\section{B. Did E-procurement Change Procurement Outcomes?}

There are three main outcome variables about which the government cares when procuring for the provision of a service/construction of a project: the price it pays for the contract, the timeliness with which the contract is executed, and the quality of work undertaken. In this section, we examine the impact of e-procurement on each of these three dimensions.

Prices.-To examine the impact on prices paid, we first consider impacts in each country on the contract value agreed upon between the winning bidder and the government. Column 1 shows no statistically significant impact in India on log contract value, conditional on the log length of the road and the log estimated cost of the road. The point estimate is quite small- 0.02 - and the 95 percent confidence interval ranges from -0.027 to 0.064 . This means that we can reject the hypothesis that there was more than 3 percent cost savings associated with e-procurement, based on the original contract value. For Indonesia, conditional on the log estimated cost, the point estimates for both works and consultancy projects suggest small reductions in log contract value, though they are not statistically significant. The confidence intervals suggest that, at 95 percent confidence, we can rule out price declines in Indonesia of more than 14.1 percent for works projects and of more than 6.6 percent for consulting projects.

Of course, the government does not care about the contract value, per se; rather, the more important measure is the actual amount paid to the contractor. Cost overruns are frequent, so as discussed above, the amount paid is typically higher than the contract value. Column 2 examines the impact on the final amount actually paid by the government, including any overruns or contract amendments. Values for this 
variable are only available for India. Note that the observation count falls substantially here, since not all packages were complete at the time of data collection. ${ }^{10}$ Again, no significant impact is observed. The point estimate for India is a 2.5 percent drop in final payments, with the 95 percent confidence interval ranging from a 8.7 percent decrease to a 3.7 percent increase. Given the uncertainty around this point estimate and that of the effect on contract values, we are not able to infer whether changes in final payments, if any, came through shifts in contract values or changes in cost overruns. On net, the evidence in this section suggests that there was no statistically detectable impact on prices paid for projects, and to the extent there are effects we cannot detect, they are not overwhelming in size.

Project Timeliness.-We next examine the first measure of quality of execution: delays in the execution of projects. In column 3 of Table 4, we consider late completion-a dummy taking value one if a project is finished after the contracted completion date and zero otherwise. ${ }^{11}$ Late completion is very common in both countries. More than three-quarters of projects in India are completed late, while 95 percent of works projects and more than half of consultancy projects in Indonesia are not finished on time. In the case of Indonesian works projects, we see a significant 16 percentage point decline in this variable associated with the adoption of e-procurement. We then consider the time overrun ratio in column 4 . This is the actual time to completion divided by the contracted time to completion. For both India and Indonesian works projects, we observe high levels of overrun-on average, actual time to completion is more than double the contracted time. However, in neither country do we see a significant decline associated with adoption of e-procurement. ${ }^{12}$

Quality.-In the final four columns of Table 4, we turn to package-level physical quality measures from a nationwide auditing process. As described above, these data only exist for the India sample. The Indian National Quality Monitoring process is coordinated centrally, and inspectors audit a randomly selected bundle of roads (both in progress and complete). Specifically, for auditing roads in a given season, the national monitor is told how many of each type of project (complete and ongoing) to sample and from which districts in a state. He then separately samples at random from the lists of projects provided by the state road department. In addition, inspectors are allocated follow-up audits for roads, and here, poorly graded roads are oversampled.

Thus, only the first quality grade is randomly selected. We examine two variables: the first quality grade and the minimal quality grade for the road project given by the national monitor. The minimum quality grade is the lowest quality grade given during any of the inspector evaluations across all contracts in the package.

\footnotetext{
${ }^{10}$ As we show subsequently, the date to completion is unaffected by e-procurement, so this type of sample selection is unlikely to be of concern.

${ }^{11}$ We do not find significant effects of e-procurement on target timeline length in either India or Indonesia. Results can be found in Table 1 of the online Appendix.

${ }^{12}$ Note that for Indonesian works, the point estimate on the time overrun ratio is positive while the dummy on late completion is negative. This is due to a few extreme outliers. If we trim the bottom and top 2.5 percent of observations, the coefficient and statistical significance in column 3 are essentially unchanged, but the point estimate in column 4 becomes -0.025 , not statistically significant.
} 
TABle 4-Prices and Project Execution

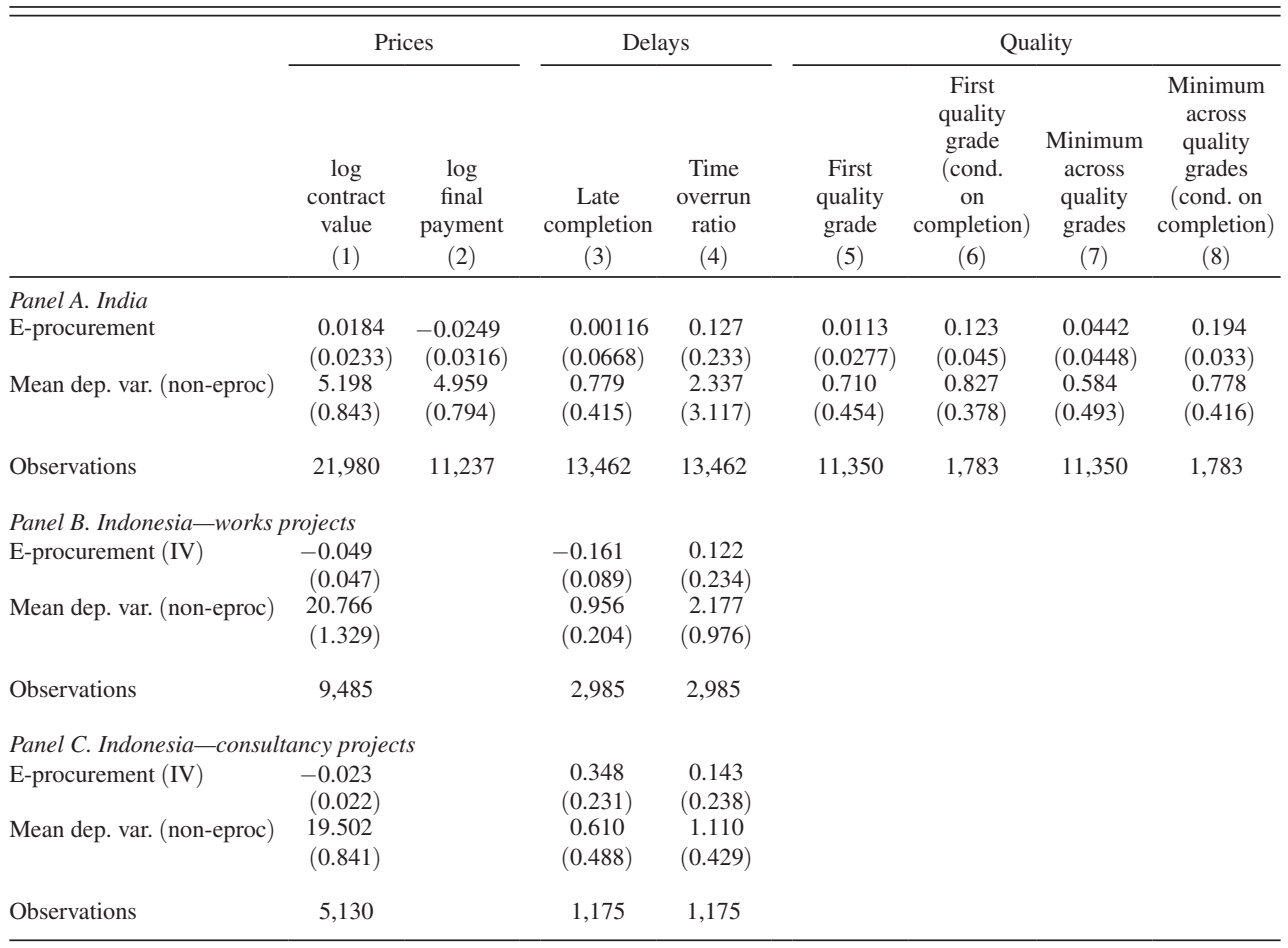

Notes: India: Columns 1, 2, and 5-8 report OLS estimates from a regression at the package level of the listed variable on an indicator for any contract in the package being awarded under e-procurement. Columns 3 and 4 report OLS estimates from a regression at the contract level of the listed variable on an indicator for the contract being awarded using e-procurement. The regression in column 1 is run on all packages for which one or more contract values were available. The values of multiple contracts in the same package were summed before taking the log. In column 2, final payment is the total amount paid out to contractors for work on the package, and the estimation sample consists of all packages for which some payment has been made. In column 3, late complete is a dummy for the project completion occurring after the contracted completion date, and time overrun ratio is the actual time to completion divided by the contracted time to completion. These two regressions are therefore run on all contracts for which both contracted and actual completion dates are listed. In columns 5 and 6 , the first quality grade is the earliest quality report (satisfactory [1] or unsatisfactory [0]) for any work done by any contractor working on the package. The minimum quality grade in columns 7 and 8 is the lowest quality grade given at any time (across all contracts in the package). Columns 5 and 7 include all packages for which inspection data is available, while columns 6 and 8 restrict to those packages which were complete when inspected. Column 5 also includes controls for complete at first inspection, first inspection year, and inspector. Column 6 includes controls for first inspection year and inspector. State and year fixed effects as well as controls for log road length and log estimated cost are included in all regressions. Indonesia: All columns report IV estimates at the project level, where the dependent variable is given in the table and the independent variable is the contract-level use of electronic procurement, instrumented by the official adoption of electronic procurement at the state level. All regressions include state and year fixed effects and a control for log estimated project cost. The delay-related variables in columns 3 and 4 were constructed using follow-up data available for a subset of projects from the roads division. Standard errors are clustered at the state level. Non-e-procurement project means for each dependent variable are also reported, with standard deviations in parentheses.

The quality score is measured as either 0 (unsatisfactory) or 1 (satisfactory). We separately consider quality outcomes for all projects (including those in progress) and for only completed roads.

In Table 4, columns 6 and 8, we find highly significant impacts on both the first and minimum quality grades for completed roads. E-procurement is associated with increases of 12.3 and 19.4 percentage points in the first quality grade and worst 
quality grade, respectively. In contrast, we do not see any significant impacts on incomplete works (columns 5 and 7). The evaluation of incomplete projects may be inherently prone to greater measurement error because a project is behind schedule, being revised, or is simply not far along enough to be accurately judged. We see no evidence in the data that e-procurement leads to more abandoned (never completed) contracts or to a differential number of incomplete projects at the time of inspection, suggesting that the difference in significance of the quality estimates cannot be explained by e-procurement driving low-quality contracts to an even lower level that results in unfinished construction.

\section{Selecting Better Contractors, or Making Existing Contractors Better?}

We observe significant impacts of e-procurement on road quality in India and evidence of reductions in delays in Indonesia. We also find that winning contractors are more likely to come from outside areas. We now explore a potential channel of influence: whether e-procurement changed the pool of contractors who bid and caused better contractors to be selected.

To the extent that e-procurement improves outcomes, an important question is whether it does so by selecting better contractors, or by encouraging existing contractors to perform better. Selection effects would occur if the main effects described above were primarily driven by e-procurement spurring new entrants, and if those new entrants won; treatment effects on existing contractors could occur if increased competition or lower corruption led these incumbent firms to submit higher quality bids.

To investigate these possibilities, we conduct a two-stage strategy where we first estimate a fixed effect for each firm in the data. This measures each firm's average quality. We then examine whether e-procurement leads to the selection of higher quality firms. If it does-and if these coefficients match the overall effects documented above-we can then conclude that selection effects play a large role. On the other hand, if e-procurement does not change average firm quality, then the quality and delay effects documented above must be arising through increased performance from a given set of incumbent firms.

For each outcome of interest $y$, we initially estimate the following regression:

$$
y_{i c s t}=\tau_{c}+\alpha_{s}+\alpha_{t}+\delta E P R O C_{s t}+\mathbf{X}_{i c s t} \gamma+\epsilon_{i c s t},
$$

where $\tau_{c}$ is a winning contractor fixed effect and $E P R O C_{s t}$ is a dummy for e-procurement adoption in state $s$ as of year $t .{ }^{13} \mathrm{We}$ include state/province and year fixed effects and controls as before. We generate a full set of contractor fixed effects from this regression and then use them as the outcome variable in the following regression:

$$
\tau_{i s t}=\alpha_{s}+\alpha_{t}+\beta E P R O C_{s t}+\mathbf{X}_{i s t}^{\prime} \gamma+\epsilon_{i s t}
$$

\footnotetext{
${ }^{13}$ For Indonesia, we additionally include the dummy variable, EPROCPACKAGE $E_{i c s t}$, to account for the fact that e-procurement adoption at the state level does not imply that all projects in that province will be tendered using e-procurement.
} 
where $\tau_{i s t}$ is the estimated $\tau_{c}$ from the initial regression for the contractor winning project ist. The estimation is weighted by the inverse variance of $\tau_{c}$ (as estimated from the first stage). This regression asks how e-procurement affected the choice of which contractors won a given package. ${ }^{14}$ Standard errors are clustered by both state and winning contractor in each stage.

Examining prices in columns 1 and 2 of Table 5, we find no evidence suggesting that the introduction of e-procurement was accompanied in either India or Indonesia with the selection of winning firms that tend to make lower or higher winning bid amounts for a given estimated cost.

We then examine delays. In column 3 , we see that for works projects in Indonesia, e-procurement was associated with firms that tended to be less late being more likely to win. The magnitude of the coefficient- 0.058 - is about one-third of the equivalent magnitude in column 3 of Table $4-0.161$-which suggests that one-third of the effect is driven by changes in selection, while two-thirds of the effect is driven by existing contractors performing better.

We also find substantial impacts on the average quality of contractors, as shown in columns 6 and 8 of Table 5. The magnitudes of these coefficients are between 50 and 80 percent of those for the overall quality effects in Table 4. This suggests that the quality effect is driven primarily by higher quality contractors being selected rather than by increased competition improving the quality of existing contractors. ${ }^{15}$

\section{Conclusion}

This paper provides some of the first rigorous evidence on the impact of e-procurement on contractual choice and subsequent contract outcomes. All told, the results present a consistent story. E-procurement appears to have led to increased ability of firms from outside the home region to win contracts. These firms, in turn, tended to be higher quality firms in general, as measured by their average delay times (in Indonesia) and average construction quality (in India). This led to improvements in the quality of roads and timeliness but no detectable changes in price.

Following the increase in competition among firms for contracts brought about by the adoption of e-procurement, a reduction in the rents accruing to winning firms may be expected to occur either through an increase in quality for a given price or a decrease in price for a given level of quality. In both the Indian and Indonesian settings examined here, we see evidence in support of improvements in quality for a given price. The fact that we observe changes on the quality margin, and that it

\footnotetext{
${ }^{14}$ For Indonesia as before, we use EPROCPACKAGE $E_{i s t}$ instrumented with $E P R O C_{s t}$ in this regression.

${ }^{15}$ In addition to improvements in terms of price and quality, ensuring the participation of smaller firms may be an outcome that is desirable from the perspective of the government and influenced by the structure of procurement (Krasnokutsaya and Seim 2011). To address the possibility of such effects here, in online Appendix Table 3 we examine whether winning contractors under e-procurement are more likely to be large firms, as proxied by whether they tend to be involved with larger projects. In India, e-procurement is associated with such a change when we consider the outcome of log road length, but there is no significant impact for estimated project cost. In Indonesia, we see some increase in contractor size for works projects but it is very noisily estimated, while no effect is observed for consulting projects. These results suggest that e-procurement results in minor, if any, changes in the distribution of winning firm size.
} 
Table 5-Two-Stage Contractor FE Regressions

\begin{tabular}{|c|c|c|c|c|c|c|c|c|}
\hline & \multicolumn{2}{|c|}{ Prices } & \multicolumn{2}{|c|}{ Delays } & \multicolumn{4}{|c|}{ Quality } \\
\hline & $\begin{array}{l}\log \\
\text { contract } \\
\text { value } \\
(1)\end{array}$ & $\begin{array}{c}\log \\
\text { final } \\
\text { payment } \\
(2)\end{array}$ & $\begin{array}{c}\text { Late } \\
\text { complete } \\
(3)\end{array}$ & $\begin{array}{l}\text { Time } \\
\text { overrun } \\
\text { ratio } \\
(4)\end{array}$ & $\begin{array}{l}\text { First } \\
\text { quality } \\
\text { grade } \\
(5)\end{array}$ & $\begin{array}{c}\text { First } \\
\text { quality } \\
\text { grade } \\
\text { (cond. on } \\
\text { completion) } \\
\text { (6) }\end{array}$ & $\begin{array}{l}\text { Minimum } \\
\text { across } \\
\text { quality } \\
\text { grades } \\
(7)\end{array}$ & $\begin{array}{c}\text { Minimum } \\
\text { across } \\
\text { quality } \\
\text { grades } \\
\text { (cond. on } \\
\text { completion) } \\
\text { (8) }\end{array}$ \\
\hline $\begin{array}{l}\text { Panel A. India } \\
\text { E-procurement }\end{array}$ & $\begin{array}{c}0.00206 \\
(0.01211)\end{array}$ & $\begin{array}{c}0.00568 \\
(0.01315)\end{array}$ & $\begin{array}{c}0.0119 \\
(0.0403)\end{array}$ & $\begin{array}{c}0.218 \\
(0.154)\end{array}$ & $\begin{array}{c}0.0214 \\
(0.0201)\end{array}$ & $\begin{array}{c}0.0973 \\
(0.0460)\end{array}$ & $\begin{array}{c}0.0181 \\
(0.0253)\end{array}$ & $\begin{array}{c}0.107 \\
(0.049)\end{array}$ \\
\hline Observations & 18,745 & 10,161 & 9,997 & 9,997 & 9,346 & 1,789 & 9,346 & 1,789 \\
\hline $\begin{array}{l}\text { Panel B. Indonesia-1 } \\
\text { E-procurement (IV) }\end{array}$ & $\begin{array}{l}\text { prks projects } \\
0.0642 \\
(0.0546)\end{array}$ & & $\begin{array}{c}-0.058 \\
(0.025)\end{array}$ & $\begin{array}{r}-0.127 \\
(0.138)\end{array}$ & & & & \\
\hline Observations & 8,352 & & 2,941 & 2,939 & & & & \\
\hline $\begin{array}{l}\text { Panel C. Indonesia- } \\
\text { E-procurement (IV) }\end{array}$ & $\begin{array}{c}\text { nsultancy } \mathrm{pr} \\
0.000007 \\
(0.00393)\end{array}$ & iects & $\begin{array}{c}-0.003 \\
(0.068)\end{array}$ & $\begin{array}{c}0.008 \\
(0.024)\end{array}$ & & & & \\
\hline Observations & 4,371 & & 948 & 955 & & & & \\
\hline
\end{tabular}

Notes: India: The first stage is an OLS estimate, where the dependent variable is given in the table and regressed on a set of winning-contractor fixed effects. The second stage regresses the estimated contract fixed effects for each contract on an indicator for the contract being awarded using e-procurement. Coefficients on the indicator from the second stage are reported. In the second stage, observations are analytically weighted by the inverse of the winning-contractor estimate squared standard errors. All regressions are run at the package level and are restricted to packages with one contract. State and year fixed effects as well as controls for log road length and log estimated cost are included in the second stage, while controls for e-procurement, log road length, and log estimated cost are included in the first stage. Indonesia: Observations are at the project level. The first stage is an OLS estimate, where the dependent variable is given in the table and regressed on a set of winning-contractor fixed effects. The second stage is an IV estimate, where the dependent variable is the winning-contractor coefficient from the first stage and the dependent variable is the use of e-procurement, instrumented by the official adoption of electronic procurement at the state level. In the second stage, observations are analytically weighted by the inverse of the winning-contractor estimate squared standard errors. All regressions include state and year fixed effects in both stages as well as a control for log estimated cost in the second stage, while controls for log estimated cost, use of e-procurement at the project level, and adoption of electronic procurement at the state level are included in the first stage. Standard errors are clustered at the state and winning contractor levels. For descriptions of the dependent variables, see Table 4.

occurs through changing which contractors win rather than the performance of a given set of winning contracts, suggests that the system prior to e-procurement was not necessarily selecting the most efficient firms, and that e-procurement may have improved efficiency even if it did not necessarily lower prices paid. It also suggests that the practice of giving contracts to the lowest price bidder likely contributed to greater inefficiencies on the quality margin.

Overall, our findings provide qualified support to the view that e-governance can improve the provision of public services. E-procurement was a partial reform, which changed the application process but neither the rules for technical qualification nor the requirement that the lowest price bidder receive the contract. Case study evidence suggests that official discretion in determining technical disqualification is often an important way of limiting competition. Equally, emphasizing price over quality (as occurs when lowest price bidder always wins) implies that bidders build in their profit margins by cutting back on quality. E-procurement facilitated entry but 
left significant discretion with officials in determining qualification, and the bidding rules continued to prioritize low price over quality. Thus, it appears that the main impact we see can be attributed to gains from trade associated with having reduced barriers to entry. It is an open question whether a reform package that changes both the application process and also the process of selecting among bidders could lead to even larger gains in economic efficiency.

\section{APPENDIX}

TABLE A1

\begin{tabular}{lc}
\hline \hline & $\begin{array}{c}\text { State level } \\
\text { inference in log contract value } \\
(1)\end{array}$ \\
\hline Panel A. India & 0.0130 \\
E-procurement & $(0.0378)$ \\
Mean dependent variable & 0.202 \\
& $(0.697)$ \\
Observations & 24 \\
Panel B. Indonesia-works projects & \\
E-procurement (IV) & -0.084 \\
Mean dependent variable & $(0.115)$ \\
& 0.086 \\
Observations & $(0.490)$ \\
Panel C. Indonesia-consultancy projects & 24 \\
E-procurement (IV) & \\
Mean dependent variable & 0.017 \\
Observations & $(0.235)$ \\
& -0.576 \\
& $(0.790)$ \\
& 21 \\
& \\
&
\end{tabular}

Notes: India: column 1 reports an OLS estimate at the state level, where the dependent variable is the difference in log average contract value between 2000 and 2001. The independent variable is the year of official adoption of electronic procurement at the state level, conditional on adoption occurring after 2001. Indonesia: column 1 reports OLS estimates at the state level, where the dependent variable is the difference in log average contract value between 2005 and 2004. The independent variable is the year of official adoption of electronic procurement at the state level, conditional on adoption occurring after 2005. Robust standard errors are in parentheses below estimates. Non-e-procurement project means for each dependent variable are also reported, with standard deviations in parentheses.

\section{REFERENCES}

Aker, Jenny C. 2010. "Information from Markets Near and Far: The Impact of Mobile Phones on Grain Markets in Niger." American Economic Journal: Applied Economics 2 (3): 46-59.

-Aker, Jenny C., Christopher Ksoll, and Travis J. Lybbert. 2012. "Can Mobile Phones Improve Learning? Evidence from a Field Experiment in Niger." American Economic Journal: Applied Economics 4 (4): 94-120.

-Asker, John. 2010. "A Study of the Internal Organization of a Bidding Cartel." American Economic Review 100 (3): 724-62.

-Asker, John, and Estelle Cantillon. 2010. "Procurement when price and quality matter." RAND Journal of Economics 41 (1): 1-34. 
Bandiera, Oriana, Andrea Prat, and Tommaso Valletti. 2009. "Active and Passive Waste in Government Spending: Evidence from a Policy Experiment." American Economic Review 99 (4): 1278-1308.

Briceño-Garmendia, Cecilia, Antonio Estache, and Nemat Shafik. 2004. "Infrastructure Services in Developing Countries: Access, Quality, Costs and Policy Reform." World Bank Policy Research Working Paper 3468.

Bobonis, Gustavo, Luis R. Cámara Fuertes, and Rainer Schwabe. 2010. "Does Exposing Corrupt Politicians Reduce Corruption?" Unpublished.

Burguet, Roberto, and Yeon-Koo Che. 2004. "Competitive procurement with corruption.” RAND Journal of Economics 35 (1): 50-68.

Cai, Hongbin, J. Vernon Henderson, and Qinghua Zhang. 2013. "China's land market auctions: Evidence of corruption?" RAND Journal of Economics 44 (3): 488-521.

Campante, Filipe, Ruben Durante, and Francesco Sobbrio. 2014. "Politics 2.0: The Multifaceted Effect of Broadband Internet on Political Participation." National Bureau of Economic Research (NBER) Working Paper 19029.

Celentani, Marco, and Juan-José Ganuza. 2002. "Corruption and competition in procurement." European Economic Review 46 (7): 1273-1303.

Decarolis, Francesco. 2014. “Awarding Price, Contract Performance, and Bids Screening: Evidence from Procurement Auctions.” American Economic Journal: Applied Economics 6 (1): 108-32.

Di Tella, Rafael, and Ernesto Schargrodsky. 2003. "The Role of Wages and Auditing during a Crackdown on Corruption in the City of Buenos Aires." Journal of Law and Economics 46 (1): 269-92.

Falck, Oliver, Robert Gold, and Stephan Heblich. 2014. "E-lections: Voting Behavior and the Internet." American Economic Review 104 (7): 2238-65.

Ferraz, Claudio, and Frederico Finan. 2008. "Exposing Corrupt Politicians: The Effect of Brazil's Publicly Released Audits on Electoral Outcomes." Quarterly Journal of Economics 123 (2): 703-45.

Freedom House. 2012. "Countries at the Crossroads 2012: Indonesia.” https://freedomhouse.org/sites/ default/files/Indonesia\%20-\%20FINAL.pdf.

Government of Indonesia. 2003. "Keputusan Presiden Republik Indonesia Nomor 80 Tahun 2003." http://bumn.go.id/data/uploads/files/1/80.pdf.

Gruber, Jonathan H., and Sendhil Mullainathan. 2005. "Do Cigarette Taxes Make Smokers Happier?" B. E. Journal of Economic Analysis and Policy 5 (1).

Indonesia Procurement Watch. 2011. "Laporan Survei: Jejak Suap Dalam Pengadaan Barang/Jasa Pemerintah." http://www.iprocwatch.org/berita/utama/173-hasilsurvei-ipw-qjejak-suap-dalampengadaan-barangjasa-pemerintahq.html (accessed January 14, 2013).

International Monetary Fund. 2008. International Financial Statistics. Washington, DC: International Monetary Fund.

Jaber, Ahmed. 2013. "Broadband Internet and Political Behavior: Evidence from the United States." Unpublished.

Jensen, Robert. 2007. "The Digital Provide: Information (Technology), Market Performance and Welfare in the South Indian Fisheries Sector." Quarterly Journal of Economics 122 (3): 879-924.

Kenny, Charles. 2007. "Construction, Corruption, and Developing Countries." World Bank Policy Research Working Paper 4271.

Krasnokutskaya, Elena, and Katja Seim. 2011. "Bid Preference Programs and Participation Highway Procurement Auctions.” American Economic Review 101 (6): 2653-86.

Leipold, Knut, and World Bank. 2007. "Electronic Government Procurement (e-GP): Opportunities and Challenges." https://www.uncitral.org/pdf/english/congress/Leipold.pdf.

Lewis-Faupel, Sean, Yusuf Neggers, Benjamin A. Olken, and Rohini Pande. 2016. "Can Electronic Procurement Improve Infrastructure Provision? Evidence from Public Works in India and Indonesia: Dataset." American Economic Journal: Economic Policy. http://dx.doi.org/10.1257/pol.20140258.

Onishi, Norimitsu. 2009. "Corruption Fighters Rouse Resistance in Indonesia." New York Times, July 25. http://www.nytimes.com/2009/07/26/world/asia/26indo.html?_r=0.

Organisation for Economic Co-operation and Development (OECD). 2002. "The Size of Government Procurement Markets." http://www.oecd.org/newsroom/thesizeofgovernmentprocurementmarkets. htm (accessed January 14, 2013).

Parlina, Ina. 2011. "Graft Cases Show Need for Procurement Law: Activists.” Jakarta Post, July 25. http://www.thejakartapost.com/news/2011/07/25/graft-cases-show-need-procurement-lawactivists.html.

Singer, Marcos, Garo Konstantinidis, Eduardo Roubik, and Eduardo Beffermann. 2009. "Does e-Procurement Save the State Money?" Journal of Public Procurement 9 (1): 58-78. 
Strömberg, David. 2004. “Radio's Impact on Public Spending.” Quarterly Journal of Economics 119 (1): 189-221.

Tran, Anh. 2008. "Can Procurement Auctions Reduce Corruption? Evidence from the Internal Records of a Bribe-Paying Firm." Unpublished.

United Nations Asia and Far East Institute (UNAFEI). 2008. "Corruption Control in Public Procurement." Presented at the Second Regional Seminar on Good Governance for Southeast Asian Countries, July 23-25, Bangkok.

World Bank International Finance Corporation. 2009. "Enterprise Surveys: Indonesia Country Profile 2009.” http://www.enterprisesurveys.org/ /media/GIAWB/EnterpriseSurveys/Documents/ Profiles/English/Indonesia-2009.pdf. 